\title{
ANALISIS BENTUK-BENTUK KERANCUAN BERBICARA PADA ANAK USIA 3-5 TAHUN (STUDI KASUS DI DAERAH KECAMATAN JAMBI TIMUR)
}

\author{
Yuliana, Erlina Zahar
}

This research is aimed at describing the types of speaking disturbance on children 3-5 years old in Kecamatan Jambi Timur. This research is descriptive qualitative. In collecting the data, the method of observation, interview, and documentation are used. The data of this research is verbal data in the form of words or utterances wich is gained from 3-5 years children in Kecamatan Jambi Timur.

The result shows that the speaking disturbance on 3-5 years old children in Kecamatan Jambi Timur are: (1) speaking disturbance which is related with Lisping by Ahmad Tri Andika 4 data, Achmad Saddam Kemal 2 data, and dominantly used by Safira Aulia Fitri 8 data, (2) speaking disturbance which is related with Slurring dominantly used by Ahmad Tri Andika 9 data, Safira Aulia Fitri 3 data, and Achmad Saddam Kemal 0 data (3) speaking disturbance which is related Stuttering 0 data and (4) speaking disturbance which is related with Cluttering only used by Safira Aulia Fitri 9 data. The type of speaking disturbance that is dominantly used by 3-5 years old children in Kecamatan Jambi Timur is speaking disturbance which is related with Lisping and Slurring, Cluttering. While speaking disturbance which is related with Stuttering is not found.

Kata kunci : Types, Speaking Disturbance, 3-5 Years Old Children

\section{PENDAHULUAN}

Kehidupan manusia seharihari tidak terlepas dari bahasa, manusia berkomunikasi dengan individu lainnya menggunakan bahasa. Bahasa sebagai alat komunikasi yang dimiliki manusia yang dihasilkan alat ucap. Hubungan manusia dan bahasa tidak dapat dipisahkan karena keduanya mempunyai peranan penting dalam perkembangan bahasa manusia. Manusia membutuhkan bahasa untuk mengekspresikan diri, beradaptasi, dan berkomunikasi pada lingkungan sosial secara lisan dan tulisan.

Manusia dalam pemerolehan bahasanya diawali pada saat manusia lahir ke dunia dan tumbuh menjadi anak-anak. Proses pemerolehan bahasa yang dilakukan anak bukan suatu hal yang mudah dilakukan. Manusia terutama anak memerlukan perhatian yang khusus dalam berbicara, hal yang menarik dari anak adalah anak selalu merekam apa yang didengar dan ditujukan kepadanya. Anak-anak terutama anak usia 3-5 tahun yang masih dalam proses belajar berbicara yang baru akan memulai menyesuaikan dan menambah perbendaharaan kata sangat membutuhkan rangsangan dari lingkungannya. Pada masa anak usia inilah dorongan dari lingkungan diperlukan karena permasalahan anak ketika baru mengenal berbahasa saat sedang berbicara menjadi hal yang sangat penting dikaji, mengingat begitu banyak anak terutama anak usia 3-5 yang sedang belajar untuk 
berbicara mengalami permasalahan gangguan dalam berbicara.

Peneliti menemukan berbagai macam permasalahan dalam kerancuan berbicara pada anak usia 35 tahun di antaranya yaitu pertama, kerancuan berbicara anak saat melafalkan huruf " $\mathrm{S}$ " menjadi " $\mathrm{T}$ " contoh "ado pak politi" (ado pak polisi) anak laki-laki berusia 5 tahun terkait dengan Lisping. Kedua, terdapat anak yang tidak dapat melafalkan huruf "S" dan "R" contoh saat anak mengatakan "ekim datang, ekim datang” (es krim datang, es krim datang) anak laki-laki usia 5 tahun terkait dengan Sluring. Ketiga, kerancuan berbicara anak saat melafalkan huruf " $R$ " menjadi "L" contoh saat anak laki-laki usia 5 tahun mengatakan kata "yok main kejalkejalan" (yok main kejar-kejaran) terkait dengan Lisping. Keempat, kerancuan berbicara anak saat berbicara cepat "unda apo ano alif tadi" (Bunda dimano Alif tadi) terkait dengan Cluttering. Hal inilah yang menjadikan salah satu motivasi peneliti untuk mengkaji lebih dalam peristiwa kerancuan berbicara pada anak usia 3-5 tahun.

\section{STUDI KEPUSTAKAAN}

John Broadus Watson dalam (ahmadi, 2009:3) "Memandang psikologi sebagai ilmu pengetahuan yang mempelajari tingkah laku tampak (lahiriah) dengan menggunakan metode observasi yang objektif terhadap rangsangan dan jawaban (respons)".

Menurut (Morgan dalam Dariyo, 2007: 4) menambahkan psikologi sebagai ilmu yang mempelajari perilaku manusia, baik perilaku yang nampak (overt) maupun yang tak nampak (covert), serta bagaimana memanfaatkan ilmu tersebut untuk dapat membantu memecahkan masalah-masalah manusia.

Psikologi mengkaji sisi-sisi manusia dari segi yang bisa diamati. Hal tersebut dikarenakan bahwa jiwa itu bersifat abstrak, sehingga tidak dapat diamati secara empiris (Chaer, 2003:2).

bahasa merupakan salah satu aspek yang tidak dapat dipisahkan dari seluruh kehidupan umat manusia. Oleh karena itulah, bahasa sampai saat ini merupakan salah satu persoalan yang sering dimunculkan dan dicari jawabannya (Hidayat, 2006:21). Dalam berbahasa manusia memiliki empat keterampilan dalam memperoleh keterampilan berbahasa yaitu mula-mula pada masa kecil kita belajar menyimak bahasa kemudian berbicara, setelah itu membaca dan menulis.

Keterampilan menyimak merupakan keterampilan yang pertama sekali di dalam keterampilan berbahasa. "Menyimak adalah suatu proses kegiatan mendengarkan lambang-lambang lisan dengan penuh perhatian, pemahaman, apresiasi, serta interpretasi untuk memperoleh informasi, menangkap isi atau pesan, serta memahami makna komunikasi yang telah disampaikan sang pembicara melalui ujaran atau bahasa lisan" (Tarigan, 2008: 31).

Keterampilan berbicara merupakan keterampilan yang kedua di dalam keterampilan berbahasa. "Berbicara adalah suatu keterampilan berbahasa yang berkembang pada kehidupan anak yang hanya didahului oleh keterampilan menyimak, dan pada masa tersebut kemampuan berbicara atau berujar dipelajari" (Tarigan, 2008: 3). 
Para pakar linguistik deskriptif biasanya mendefenisikan bahasa sebagai "Satu sistem lambang bunyi yang bersifat arbitrer yang kemudian lazim untuk berinteraksi dan mengidentifikasi diri" (Chaer, 2003: 30).

Menurut (Bromley dalam Nurbiana, 2008:11) mendefinisikan "Bahasa sebagai sistem simbol yang teratur untuk mentransfer berbagai ide maupun informasi yang terdiri dari simbol-simbol visual maupun verbal".

Menurut (Dardjowidjojo, 2008:16) "Bahasa adalah suatu sistem simbol lisan yang arbitrer yang dipakai oleh anggota suatu masyarakat bahasa untuk berkomunikasi dan berinteraksi antar sesamanya, berlandaskan pada budaya yang mereka miliki bersama". Berdasarkan pendapat para ahli di atas maka dapat disimpulkan bahwa bahasa mempunyai peranan penting dalam berinteraksi sesama masyarakat, bahasa juga mempunyai peranan penting dalam kegiatan berkomunikasi, melalui bahasa juga suatu masyarakat dapat mengidentifikasikan dirinya.

Wardhaugh mengatakan bahwa fungsi bahasa dikatakan lisan dan tulisan karena bahasa dapat diungkapkan dan bahasa dapat dijadikan tulisan. "Fungsi ini sudah mencakup lima fungsi dasar yang menurut Kinneavy disebut fungsi ekspresi, fungsi informasi, fungsi eksplorasi, fungsi persuasi, dan fungsi entertainmen " (Michel 1967 dalam Chaer, 2003:33).

Kehidupan manusia tidak terlepas dari bahasa maka "Secara umum fungsi bahasa adalah sebagai alat komunikasi, bahkan dapat dipandang sebagai fungsi utama dari bahasa" (Hidayat, 2006: 26).
Berbicara tentang fungsifungsi bahasa, nama Halliday seorang linguis ternama tidak dapat ditinggalkan. Melalui karyanya berjudul 'Explorations in the Functions of Language' menunjukkan tujuh fungsi bahasa. Ketujuh fungsi bahasa itu dapat disebutkan Halliday (dalam Rahardi, 2009: 6) sebagai berikut: (1) fungsi instrumental, (2) fungsi regulasi, (3) fungsi representasional, (4) fungsi interaksional, (5) fungsi personal (6) fungsi heuristik, (7) fungsi imaginatif. Berdasarkan penjelasan tentang fungsi bahasa, dapat disimpulkan bahwa bahasa merupakan hal yang sangat diperlukan oleh setiap manusia, karena melalui bahasa manusia dapat berkomunikasi dan berinteraksi dengan manusia sosial dalam kehidupannya.

Bahasa Indonesia memiliki kedudukan yang sangat penting yang tercantum di dalam ikrar ketiga sumpah pemuda dan Undang-Undang Dasar RI 1945 Bab XV pasal 36 Maka kedudukan bahasa Indonesia adalah sebagai berikut:

1. Bahasa Nasional

Kedudukannya berada di atas bahasa-bahasa daerah. Hasil perumusan Seminar Politik Bahasa Nasional yang diselenggarakan di Jakarta pada tanggal 25-28 Februari 1975 menegaskan bahwa dalam kedudukannya sebagai bahasa nasional. Bahasa Indonesia berfungsi sebagai lambang kebanggaan nasional, lambang identitas nasional, alat pemersatu berbagai masyarakat yang berbeda sosial dan budaya, serta alat penghubung antar budaya antar daerah.

2. Bahasa Negara

Hasil perumusan seminar Politik Bahasa Nasional yang 
diselenggarakan di Jakarta pada tanggal 25-28 Februari 1975 dikemukakan bahwa di dalam kedudukannya sebagai bahasa negara, bahasa Indonesia berfungsi sebagai Bahasa resmi kenegaraan, bahasa pengantar resmi di lembaga-lembaga pendidikan, bahasa resmi di dalam perhubungan pada tingkat nasional dan pelaksanaan pembangunan.

Jika dilihat dari dimensi medianya, bahasa dapat dikelompokkan menjadi dua, yakni bahasa ragam lisan dan bahasa ragam tulis. Bahasa ragam lisan dapat diperinci menjadi dua, yakni (a) bahasa ragam lisan baku dan (b) bahasa ragam lisan tidak baku. Bahasa ragam lisan baku misalnya ketika orang berceramah di depan para dosen atau mahasiswa, sedangkan bahasa ragam lisan tidak baku misalnya ketika orang sedang mengobrol (Rahardi, 2009:17).

Menurut (Harley dalam Djardowidjojo, 2005: 7) menyebut "Psikolinguistik sebagai suatu "studi tentang proses-proses mental dalam pemakaian bahasa". Psikolinguistik mencoba menguraikan proses-proses psikologi yang berlangsung jika seseorang mengucapkan kalimatkalimat yang didengarnya pada waktu berkomunikasi, dan bagaimana kemampuan berbahasa itu diperoleh oleh manusia (Slobin; Meller; Slama Cazahu dalam Chaer, 2003: 5).

Menurut Dardjowidjojo (2005:2) "Psikolinguistik merupakan ilmu hibrida yakni gabungan dari dua ilmu psikologi dan linguistik". Menurut (Kess Dardjowidjojo, 2005: 3) bahwa tahap-tahap perkembangan psikolinguistik di Benua Amerika dapat dibagi 4 tahap yaitu: 1) tahap formatif, 2) tahap linguistik, 3) tahap kognitif, dan 4) tahap teori psikolinguistik.

"Psikolinguistik merupakan ilmu yang menguraikan proses-proses psikologis yang terjadi apabila seseorang menghasilkan kalimat dan memahami kalimat yang didengarnya ketika berkomunikasi dan bagaimana kemampuan berbahasa itu diperoleh manusia" (Achmad, 2012: 103).

Secara rinci psikolinguistik mempelajari empat topik utama yaitu : (a) komprehensi, yakni prosesproses mental yang dilalui oleh manusia sehingga mereka dapat menangkap apa yang dikatakan orang dan memahami apa yang dimaksud, (b) produksi, yakni proses-proses mental pada diri kita yang membuat kita dapat berujar seperti yang kita ujarkan, (c) landasan biologis serta neurologis yang membuat manusia bisa berbahasa, dan (d) pemerolehan bahasa, yakni bagaimana anak memperoleh bahasa mereka (Dardjowidjojo, 2005:7).

Pemerolehan bahasa atau akuisisi bahasa adalah proses yang berlangsung dalam otak seseorang kanak-kanak ketika dia memperoleh bahasa pertamanya atau bahasa ibunya (Chaer, 2003:167). Ada dua proses yang terjadi ketika seorang kanak-kanak sedang memperoleh bahasa pertamanya, yaitu proses kompetensi dan proses performansi.

Pengertian lain mengatakan bahwa pemerolehan bahasa memiliki suatu permulaan yang gradual yang muncul dari prestasi-prestasi mesin/motor, sosial, dan kognitif pralinguistik (Mc Graw dalam Tarigan, 2011: 5).

Pemerolehan bahasa merupakan suatu usaha yang melewati proses-proses dalam penerimaannya. "Pemerolehan bahasa 
(language acguisition) adalah suatu proses yang dipergunakan anak-anak untuk menyesuaikan serangkaian hipotesis yang rumit, ataupun teoriteori yang masih terpendam atau tersembunyi dengan ucapan-ucapan orang tuanya sampai dia memilih, berdasarkan suatu ukuran atau takaran penilaian, tata bahasa yang paling baik serta yang paling sederhana dari bahasa tersebut" (Kiparsky, 1968 dalam Rahima 2006:28). Anak-anak memperoleh bahasa pertamanya dari seorang ibu, proses pemerolehan bahasa yang didapat anak itu sangat mempengaruhi perkembangan bahasa anak.

Penelitian yang dilakukan terhadap perkembangan bahasa anak tentunya tidak terlepas dari pandangan, hipotesis, atau teori psikologi yang dianut. Pandangan Nativisme berpendapat bahwa penguasaan bahasa pada kanak-kanak bersifat alamiah (nature), dan pandangan behaviorisme yang berpendapat bahwa penguasaan bahasa pada kanak-kanak bersifat "suapan" (nurture). Pandangan ketiga dari Jean Piaget yang berpendapat bahwa penguasaan bahasa adalah, "Kemampuan yang berasal dari pematangan kognitif, sehingga pandangannya disebut kognitivisme" (Chaer, 2003: 221).

Telah berulang-ulang dikatakan bahwa bahasa yang berwujud bunyi itu dihasilkan oleh alat bicara manusia. Untuk sampai dimengerti orang lain, bahasa tersebut melalui suatu proses. Menurut (Moulton dalam Pateda, 1994:7) ada sebelas tahap yang berbeda dalam seluruh proses bahasa. Sebagai berikut: (1) membuat kode semantis, (2) membuat kode gramatikal, (3) membuat kode fonologis, (4) perintah otak, (5) gerakan alat ucap, (6) bunyi berupa getaran, (7) perubahan getaran melalui telinga pendengar, (8) getaran diteruskan ke otak, (9) pemecahan kode fonologis, (10) pemecahan kode gramatikal, dan (11) pemecahan kode semantis.

Para pakar psikolinguistik sepakat bahwa proses dan sifat pemerolehan bahasa itu berjalan dinamis serta berlangsung lewat sebuah pertahapan serta berjenjang selain itu mereka juga sepakat bahwa pemerolehan bahasa itu juga sangat dipengaruhi oleh penggunaan bahasa sekitar (Hurlock dalam Rahima, 2006:32). Tahapan tersebut yaitu tangisan, ocehan, celotehan dan isyarat.

Perkembangan yang bersifat urutan hanyalah merupakan suatu daftar prestasi atau kecakapan dalam masa tertentu. Urutan perkembangan pemerolehan bahasa dapat dibagi atas tiga bagian penting: (1) perkembangan prasekolah, perkembangan ujaran kombinatori, (3) perkembangan masa sekolah (Tarigan, 2011:16).

Pada periode belajar bahasa, seringkali anak mengalami kerancuan bicara yang sifatnya umum. Menurut (Hurlock 1978 dalam Rahima, 2006: 49) membagi kerancuan bicara masa kanak-kanak menjadi empat.

Bentuk-bentuk kerancuan berbicara, secara garis besar ada 4 yakni: lipsing, sluring, stuttering dan clutering. Keempat bentuk tersebut akan dijelaskan sebagai berikut:

- Lisping berarti penggantian huruf.

- Sluring adalah bicara yang tidak jelas

- Stuttering (menggagap) adalah keragu-raguan 
- Cluttering adalah berbicara dengan cepat dan membingungkan.

Gangguan wicara yang dialami seseorang ada pula kaitannya antara proses pemerolehan dan macam-macam gangguan yang ada. Dalam pembicaraan lain akan kita dengar berbagai macam gangguan yang dinamakan afasia (Dardjowidjojo, 1991:78). Menderita afasia Broca, khususnya yang dikenal dengan nama dysarthria, kesukaran dalam mengatur artikulasi bunyi dan karenanya menjadi "pelo" (slurring) atau kembali ke bunyi-bunyi dasar yang memang paling mudah diucapkan.

Berdasarkan penjelasan di atas, Maka peneliti hanya menggunakan teori dari Hurlock untuk dijadikan pembahasan dan mempertegas bentuk-bentuk kerancuan berbicara pada anak usia 35 tahun.

\section{METODE PENELITIAN}

Jenis penelitian yang digunakan dalam penelitian ini adalah jenis penelitian deskriptif kualitatif, jenis penelitian deskriptif ini adalah jenis penelitian yang bertujuan membuat deskripsi berdasarkan riset yang dilakukan peneliti. Dalam penelitian ini, data yang dikumpulkan bukanlah angka-angka, namun berupa kata-kata atau penggambaran sesuatu secara objektif. Penelitian seperti sering juga disebut dengan kualitatif.

Menurut (Moleong, 2012: 4)

"Penelitian kualitatif sebagai prosedur penelitian yang menghasilkan data deskriptif berupa kata-kata tertulis atau lisan dari orang-orang dan perilaku yang dapat diamati". Jenis penelitian kualitatif ini merupakan cara yang digunakan peneliti untuk mendapatkan kata yang tertulis, ucapan dari seseorang, serta tingkah laku atau perbuatan yang akan diteliti.

Sejalan dengan defenisi tersebut, Kirk dan Miller (dalam Moleong, 2012:4) mendefenisikan bahwa penelitian kualitatif adalah tradisi tertentu dalam ilmu pengetahuan sosial yang secara fundamental bergantung dari pengamatan pada manusia baik dalam kawasannya maupun dalam peristilahannya.

Berdasarkan konsep yang telah peneliti jelaskan di atas maka metode ini digunakan untuk menjelaskan bentuk-bentuk kerancuan berbicara anak usia 3-5 tahun yang digunakan peneliti sebagai objek penelitian.

Dalam penelitian ini yang menjadi populasi adalah anak usia 3-5 tahun yang berada di Kecamatan Jambi Timur Kota Jambi. Pada penelitian ini peneliti menetapkan beberapa orang yang akan menjadi sampel (informan) yang berjumlah 3 orang anak masing-masing berusia 3,4,5 tahun. Teknik pengambilan sampel secara pusposive sampling diambil berdasarkan pertimbangan subyektif penulis, di mana persyaratan yang dibuat sebagai kriteria harus dipenuhi sebagai sampel (Subagyo, 2015: 31).

Penelitan ini dilakukan di Rumah informan yang berlokasi di Kecamatan Jambi Timur Kota Jambi. Penelitian dimulai dari pra riset yang dilakukan pada bulan Maret 2017 kemudian pengajuan judul dimulai pada 20 Maret 2017 selanjutnya penulisan proposal dilakukan pada bulan April 2017.

Sumber data utama dalam penelitian ini ialah kata-kata. Katakata merupakan sumber data yang 
diperoleh dari lapangan dengan mengamati atau mewawancarai. Data sekunder dalam penelitian ini adalah sumber pendukung berupa literatur yang berkaitan dengan kerancuan berbicara anak diantaranya buku psikolinguistik, buku perkembangan bahasa anak, buku tata tulis pedoman penulisan skripsi, dan buku metode penelitian.

Sumber data primer diperoleh melalui observasi, dan membuat daftar pertanyaan. Kemudian sumber data sekunder diperoleh dari berbagai pustaka, di antaranya perpustakaan Fakultas Keguruan dan Ilmu Pendidikan, Perpustakaan Universitas Batanghari Jambi, perpustakaan daerah Provinsi Jambi, dan kantor bahasa Provinsi Jambi.

Teknik pengumpulan data yang digunakan adalah sebagai berikut:

1. Observasi

Dalam teknik ini penulis melakukan pengamatan kepada anak untuk mendapatkan data yang diperlukan.

2. Wawancara

Dalam penelitian ini, peneliti melakukan teknik wawancara untuk mendapatkan informasi. Dalam teknik wawancara ini penulis melakukan wawancara terhadap anak untuk memperoleh informasi.

3. Dokumentasi

Dalam penelitian ini, penulis menggunakan metode dokumentasi dengan menggunakan gambar.

4. Studi Pustaka

Dalam penelitian ini, penulis menggunakan metode studi pustaka untuk pencarian data dan informasi melalui dokumendokumen, baik dokumen tertulis, foto-foto, gambar, maupun dokumen elektronik yang dapat mendukung dalam proses penulisan.

Instrumen penelitian dalam penelitian ini peneliti menggunakan sebagai berikut:

1. Perekam Suara

Dalam penelitian ini, peneliti menggunakan handphone melalui aplikasi perekam suara untuk merekam pembicaraan dari informan.

2. Kamera Video

Dalam penelitian ini, peneliti menggunakan kamera video dari handphone untuk merekam aktifitas saat berlangsungnya pengambilan data, hal ini digunakan juga sebagai pembuktian bahwa peneliti benar-benar melakukan penelitian.

3. Laptop

Penulis menggunakan laptop untuk menarik perhatian anak agar tertarik melihat gambargambar yang peneliti siapkan untuk mendapatkan jawaban dari pembicaraannya.

4. Daftar Pertanyaan

Karena penelitian ini dilakukan terhadap anak usia 3-5 tahun yang belum mengerti menjawab pertanyaan dengan cara tertulis, maka dari itu peneliti menggunakan daftar pertanyaan dengan memperlihatkan dan menanyakan gambar-gambar yang penulis siapkan untuk anak memberikan jawaban secara lisan melalui pembicaraannya.

Dalam teknik analisis data ini menggunakan teknik analisis dan deskripsi. Kemudian peneliti memasukan data tersebut ke dalam tabel tabulasi data dengan tujuan 
untuk mempermudah bagi peneliti untuk mencapai tujuan penelitian ini tentang bentuk-bentuk kerancuan berbicara pada anak usia 3-5 tahun.

\section{HASIL PENELITIAN DAN PEMBAHASAN}

Pada penelitian ini penulis menemukan sebanyak 35 data. Berdasarkan data yang diperoleh, penulis menemukan beberapa bentuk kerancuan berbicara. Penulis menemukan 3 dari 4 bentuk-bentuk kerancuan berbicara pada anak usia 3 5 tahun di daerah Kecamatan Jambi Timur ialah sebagai berikut :

1. Lisping

2. Slurring

3. Stuttering

4. Cluttering

Keempat bentuk kerancuan berbicara di atas lebih lanjut dikemukakan pada pembahasan.

1. Lisping

Anak laki-laki usia 3 tahun yang bernama Dika. Hal tersebut dapat diketahui berdasarkan hasil analisis pada kata /disitulah/ menjadi /dicitulah/ terjadi penggantian huruf $/ s /$ menjadi /c/, pada kata /harimau/ menjadi /halimau/ terjadi penggantian huruf $/ r /$ menjadi $/ l /$, pada kata /dak ado/ menjadi /kak ado/ terjadi penggantian huruf $/ d /$ menjadi $/ k /$, dan pada kata /tembakan/ menjadi /tembanan/ terjadi penggantian huruf $/ k /$ menjadi $/ n /$.

Anak perempuan usia 4 tahun yang bernama Safira. Hal tersebut dapat diketahui berdasarkan hasil analisis pada kata /biru/ menjadi /biyu/ terjadi penggantian huruf $/ r /$ menjadi /y, pada kata /robot/ menjadi /kobok/ terjadi penggantian huruf $/ r /$ menjadi $/ \mathrm{k} / \mathrm{dan} / \mathrm{t} / \mathrm{menjadi} / \mathrm{k} /$, pada kata /cowok/ menjadi /kowok/ terjadi penggantian huruf $/ c /$ menjadi $/ k /$, pada kata /ular/ menjadi /iyal/ terjadi penggantian huruf $/ u /$ menjadi /i/, /l/ menjadi $/ y /$ dan $/ r /$ menjadi $l /$, dan pada kata /orang/ menjadi /olang/ terjadi penggantian huruf $/ o /$ menjadi $/ i /, / r /$ menjadi $/ y /$.

Anak laki-laki usia 5 tahun bernama Sadam, terdapat pula kerancuan berbicara. Hal tersebut dapat diketahui berdasarkan hasil analisis. Pada kata /helikopter remot/ menjadi /helikoptel lemot/ terjadi penggantian huruf $/ r /$ menjadi $/ / /$, pada kata /Sadam mau pistol/ menjadi /thadam mau pithtol/ terjadi penggantian huruf $/ s /$ menjadi th $/$.

2. Slurring

Anak usia 3 tahun yang bernama Dika. Hal tersebut dapat diketahui berdasarkan hasil analisis pada kata /helikopter/ menjadi /kopter/ terjadi ketidakjelasan dalam pengucapan huruf $/ h /$, lel, $/ l$, /i/, pada kata /nengok/ menjadi /engok/ terjadi ketidakjelasan dalam pengucapan huruf $/ n /$, pada kata /di sanolah/ menjadi /di anolah/ terjadi ketidakjelasan dalam pengucapan huruf $/ s /$, pada kata /ado ludah/menjadi /ado udah/ terjadi ketidakjelasan dalam pengucapan huruf $/ /$ dan pada kata /matahari/ menjadi 
/tahali/ terjadi ketidakjelasan dalam pengucapan huruf $/ \mathrm{m} /$ dan $/ a /$.

Anak usia 4 tahun yang bernama Safira terdapat pula kerancuan berbicara. Hal tersebut dapat diketahui berdasarkan hasil analisis pada kata /kapal/ menjadi /kapa/ terjadi ketidakjelasan dalam pengucapan huruf /1/, pada kata /rumput/ menjadi /umput/ terdapat ketidakjelasan dalam pengucapan huruf $/ r /$, dan pada kata /tembakan/ menjadi /tembaan/ terjadi

ketidakjelasan dalam

pengucapan huruf $/ k$.

3. Stuttering

Berdasarkan data dan hasil penelitian yang didapat oleh peneliti, dari ketiga anak yang bernama Dika, Safira, dan Saddam diantara mereka tidak terdapat yang mengalami bentuk kerancuan berbicara terkait dengan Stuttering.

4. Cluttering

Anak perempuan yang bernama Safira berusia 4 tahun. Hal tersebut dapat diketahui berdasarkan hasil analisis pada kata /motor balap bapak polisi/ menjadi /motoy bayap bapak cici/ terjadi pengucapan yang membingungkan yaitu pada pengucapan /motor/ menjadi /motoy/, /balap/ menjadi /bayap/, dan /bapak polisi/ menjadi /bapak cici/. Terdapat penggantian huruf $/ r /$ menjadi $/ y /$, huruf $/ / /$ menjadi $/ y /$, huruf $/ /$ menjadi / $c$, huruf $/ s /$ menjadi $/ c /$ dan terdapat penghilangan huruf $/ p /$ dan /o/. Pada kata /di atas genteng/ menjadi /di atah enteng/ terjadi penggantian huruf $/ s /$ menjadi $/ h /$ dan penghilangan huruf $/ g /$. Sementara pada kata /di atas awan/ menjadi /di atah awang/ terjadi penggantian huruf $/ s /$ menjadi $/ h /$ dan penambahan huruf $/ g /$.

\section{KESIMPULAN}

Berdasarkan hasil penelitian dan pembahasan yang dilakukan penulis pada bab IV mengenai bentuk-bentuk kerancuan berbicara pada anak usia 35 tahun (studi kasus di daerah Kecamatan Jambi Timur) maka dapat disimpulkan sebagai berikut.

1. Bentuk kerancuan berbicara pada anak usia 3-5 tahun di daerah Kecamatan Jambi Timur yang terkait dengan Lisping. Ditemukan data sebanyak 4 data dari 9 kutipan data pada Dika usia 3 tahun yang meliputi $/ s /$ menjadi $/ c /, / r /$ menjadi $/ / /$ dan /d/ menjadi $/ k /$ dan $/ k /$ menjadi $/ n /$. Sementara pada Safira usia 4 tahun ditemukan sebanyak 8 data dari 8 kutipan data yang meliputi $/ r /$ menjadi $/ y /, / r /$ menjadi $/ \mathrm{k} /, \mathrm{t} / \mathrm{m}$ menjadi $/ \mathrm{k} / \mathrm{l} / \mathrm{c} / \mathrm{menjadi} / \mathrm{k} /$, $/ u /$ menjadi $/ i /, / /$ menjadi $/ y /, / r /$ menjadi $/ r /$ menjadi $/ l /, / o /$ menjadi /i/. Sedangkan pada Sadam usia 5 tahun ditemukan sebanyak 2 data dari 12 kutipan data yang meliputi $/ r /$ menjadi $/ /$ dan $/ s /$ menjadi $/ t h /$.

2. Bentuk kerancuan berbicara pada anak usia 3-5 tahun di daerah Kecamatan Jambi Timur yang terkait dengan Slurring. Ditemukan data sebanyak 9 data dari 6 kutipan data pada Dika usia 3 tahun yang meliputi $/ \mathrm{h} / \mathrm{l} / \mathrm{e} / \mathrm{ll} / \mathrm{i} /$ untuk kata /helikopter/ menjadi /kopter/, /n/ untuk kata /nengok/ 
menjadi /engok/,/s/ untuk kata /di sanolah/ menjadi /di anolah/, /l/ untuk kata /ado ludah/ menjadi /ado udah/ dan $/ \mathrm{m} / \mathrm{l} / \mathrm{a} / \mathrm{untuk}$ kata /matahari/ menjadi /tahali/. Sementara data yang ditemukan pada Safira usia 4 tahun ditemukan sebanyak 3 data dari 3 kutipan data meliputi /1/ untuk kata /kapal/ menjadi /kapa/, /r/ untuk kata /rumput/ menjadi /umput/, / $k$ / untuk kata /tembakan/ menjadi /tembaan/. Sedangkan pada Sadam usia 5 tahun data Slurring tidak ditemukan.

3. Bentuk kerancuan berbicara pada anak usia 3-5 tahun di daerah Kecamatan Jambi Timur yang terkait dengan Stuttering berdasarkan hasil penelitian dan data tidak ditemukan pada Dika, Safira dan Sadam.

4. Bentuk kerancuan berbicara pada anak usia 3-5 tahun di daerah Kecamatan Jambi Timur yang terkait dengan Cluttering. Ditemukan data sebanyak 9 dari 3 kutipan data dari Safira anak perempuan berusia 4 tahun yang meliputi $/ r /$ menjadi $/ y /$ pada kata /motor/, $/ /$ menjadi $/ y /$ pada kata /balap/, $/ p /$ dan $/ o /, ~ / /$ menjadi $/ c /$ dan $/ s /$ menjadi $/ c /$ pada kata /polisi/, /s/ menjadi / $h$ / pada kata /di atas/, penghilangan huruf / $/ g /$ pada kata /genteng/, dan penambahan huruf $/ g /$ pada kata /awan/. Sementara pada Dika usia 3 tahun dan Sadam 5 tahun data mengenai bentuk kerancuan berbicara Cluttering tidak ditemukan.

\section{SARAN}

Berdasarkan hasil kesimpulan, penulis menyarankan sebagai berikut.
1. Bagi orang tua disarankan agar tidak mengganti-ganti pelafalan huruf dalam berbicara kepada anak. Hal ini bertujuan agar anak memahami penggunaan dan pelafalan huruf yang benar.

2. Diharapkan kepada orang tua untuk membiasakan anak berbicara dengan jelas terutama intonasi dan pelafalan tertentu misalnya dalam kata 'di sano' menjadi 'di ano' pelafalan $/ s /$ harus dilafalkan dengan jelas. Hal ini bertujuan agar anak tidak menghilangkan pelafalan huruf dari kata yang diucapkan.

3. Bagi orang tua diharapkan agar tidak berbicara yang terlalu cepat kepada anak. hal ini bertujuan agar anak tidak merasa bingung untuk memahami kata yang didengar.

4. Penelitian ini baru berupa penelitian tahap awal. Oleh karena itu, disarankan kepada penulis lain untuk mengkaji objek ini dari aspek yang berbeda. Maka diharapkan penulis lain dapat melanjutkan penelitian ini dengan cara mengubah objek kajian dan melanjutkan penelitian ini untuk mengetahui faktor-faktor penyebab terjadinya kerancuan berbicara anak yang pada muara akhirnya dapat menambah khazanah ilmu bahasa, khususnya yang terjadi pada bahasa anak-anak.

\section{DAFTAR PUSTAKA}

Achmad dan Alek Abdullah. 2012.

Linguistik Umum. Jakarta: Erlangga

Ahmadi, Abu. 2009. Psikologi

Umum. Jakarta: Rineka Cipta 
Aliah,

Saripah

Http://repository.upi.edu/id/eprint/506

9/29052017

Alwasilah, A Chaedar. 2005. Pengantar Penelitian Linguistik Terapan. Jakarta: Pusat Bahasa Departemen Pendidikan Nasional.

Alwi, Hasan dan Dendy Sugono. 2000. Politik Bahasa. Jakarta: Pusat Bahasa Departemen Pendidikan Nasional.

Anggraini, Wenty

Http://lib.unnes.ac.id/2802/1/3 489.pdf/29052017

Arikunto, Suharsimi. 2013. Prosedur Penelitian; Suatu Pendekatan Praktik. Jakarta: Rineka Cipta

Chaer, Abdul. 2003. Psikolinguistik:

Kajian Teoritis. Jakarta: Rineka Cipta

Dardjowidjojo, Soenjono. 1991. Pertemuan Linguistik Lembaga Bahasa Atmajaya; keempat. Jakarta: Kanisius

Dariyo, Agoes. 2007. Psikologi Perkembangan Anak Usia Tiga Tahun Pertama. Bandung: Refika Aditama

Darjowidjojo, Soenjono. 2005. Psikolinguistik Pengantar Pemahaman Bahasa Manusia. Jakarta: Yayasan Obor Indonesia.
Dhieni, Nurbiana. 2008. Metode Pengembangan Bahasa. Jakarta: Universitas Terbuka.

Hidayat, Asep Ahmad. 2006. Filsafat

Bahasa. Bandung: PT Remaja

Rosdakarya.

Https://www.kamusbesar.com/daftar-

pertanyaan 29052017

Http://bahtiarthiar.blogspot.co.id/201 5/06/perkembangan-bahasapertama.htmljm $=1$

$\begin{array}{crr}\text { Moleong. 2012. } & \text { Metodologi } \\ \text { Penelitian } & & \text { Kualitatif. } \\ \text { Bandung: } & \text { PT } & \text { Remaja } \\ \text { Rosdakarya. } & & \end{array}$

Pateda. Mansoer. 1994. Linguistik:

Sebuah Pengantar. Bandung:

Angkasa.

Rahardi, Kunjana. 2009. Bahasa Indonesia untuk Perguruan Tinggi. Jakarta: Erlangga.

Rahima, Ade. 2006. Dasar-Dasar Psikolinguistik: Suatu Tinjauan Psikologi Bahasa.

Subagyo, Joko. 2015. Metode Penelitian Dalam Teori dan Praktik. Jakarta: Rineka Cipta.

Sudaryanto. 1993. Metode dan Aneka teknik Analisis Bahasa. Duta Wacana University Press.

Tarigan, H.G. 2008. Berbicara Sebagai Suatu Keterampilan 
Berbahasa. Bandung:

Angkasa

Tarigan, H.G. 2008. Menyimak Sebagai Suatu Keterampilan Berbahasa. Bandung: Angkasa

Tarigan, H.G. 2011. Pengajaran Pemerolehan Bahasa. Bandung: Angkasa.

Trinowismanto, YosepHttps://reposito ry.usd.ac.id/6172/2/10122404 3full.pdf29052017

Wahya, Suzana dan Ernawati Waridah. 2013. Kamus Bahasa Indonesia. Bandung: Ruang Kata.

Wikipedia

Https://id.m.Wikipedia.org/wi

ki/perekam-suara29052017

Wikipedia

Https://id.m.wikipedia.org/wi

$\underline{\mathrm{ki} / \text { video-kamera29052017 }}$

Wikipedia

Https://id.m.wikipedia.org/wi

$\underline{\text { ki/komputer-jinjing29052017 }}$

Yendra. 2016. Mengenal Ilmu Bahasa; Linguistik.

Yogyakarta: Deepublish 